\title{
Construction Practices Contributing to Rising Damp in Kumasi Metropolitan and Ejisu Municipal Assemblies in Ghana
}

\author{
Richard Oduro Asamoah, ${ }^{1}$ John Solomon Ankrah, ${ }^{2}$ Philip Bannor, ${ }^{1}$ and Kofi Ofei-Nyako \\ ${ }^{1}$ Construction Division, Council for Scientific and Industrial Research (CSIR), Building and Road Research Institute (BRRI), \\ Kumasi, Ghana \\ ${ }^{2}$ Structures, Design and Planning Division, Council for Scientific and Industrial Research (CSIR), \\ Building and Road Research Institute (BRRI), Kumasi, Ghana
}

Correspondence should be addressed to Richard Oduro Asamoah; richardasamoah760@yahoo.com

Received 2 March 2017; Revised 19 May 2017; Accepted 24 July 2017; Published 24 August 2017

Academic Editor: Eric Lui

Copyright (C) 2017 Richard Oduro Asamoah et al. This is an open access article distributed under the Creative Commons Attribution License, which permits unrestricted use, distribution, and reproduction in any medium, provided the original work is properly cited.

\begin{abstract}
Buildings represent significant investment of developers and, as such, it is important to ensure value for the capital injected into the construction of buildings. Unfortunately, due to neglect of proper construction practices, buildings are facing defects, and one of such defects is rising damp. This study sought to identify some of the construction practices contributing to rising damp in buildings and their effects and suggest some remedial measures for controlling and treatment of rising damps. Snowball sampling and purposive sampling techniques were used to gather data from a cross section of 78 building environment professionals in Kumasi and Ejisu who have experienced the effects of moisture rise. Relative Importance Index was used to rank the significance of the causes. The study revealed that failure to use damp-proof membrane or course, presence of groundwater, porosity of masonry, and concrete element sand flooding were the main causes of rising damp. Undersetting and saw slotting, making good plumbing leakages, using approved waterproof chemical injection, and application of admixtures were the main measures recommended to avert rising damp.
\end{abstract}

\section{Introduction}

Buildings have been facing the phenomenon of rising damp [1]. Rising damp is the upward movement of moisture through permeable materials by capillary action [2]. Water rises through the pores in the masonry via a process called capillarity. Capillarity is a process whereby water molecules are electrochemically attracted to mineral surfaces, enabling water to move vertically through pores of a certain size despite the counteractive force of gravity [3,4]. Rising damp is caused by capillary suction of the fine pores that occur in all masonry materials [5]. The capillaries draw water from the soils beneath a building against the force of gravity, leading to damp zones at the base of walls $[4,5]$. Large temperature changes and increasing rates of evaporation trigger more upward, water movement in walls, resulting in the process called salt crystallization [6]. The presence of groundwater is a common source for moisture rise contributing to rising damp in the masonry walls. The higher the groundwater table, the more severe the rising damp [7]. Water table differs from one place to another depending on the geographical locations of buildings and the type of soils. According to Charola [8], groundwater contains sulphates, chlorides, and nitrates, which are hygroscopic. The presence of these chemicals in large volumes result in visual signs of dampness and tidal marks on walls. Rising damp causes masonry material to disintegrate, leading to high cost of maintenance [8]. Moisture penetrates permeable materials and dissolves soluble salts causing flaking of plastered surface, fungal and mould attack, and corrosion of reinforcements [9]. According to the World Health Organization regional report for Europe on damp and mould, rising damp can cause health risk [10]. Also presence of rising damp can lead to contractual agitations among building professionals and their clients [11]. This study therefore investigates the causes, effects, and some construction practices contributing to rising damp in 
TABLE 1: Porosity of building materials in percentages.

\begin{tabular}{lcc}
\hline Number & Material & \% of porosity \\
\hline 1 & Cement render & 0.20 \\
2 & Brick & 0.35 \\
3 & Granite & 0.02 \\
4 & Sandstone & $0.05-0.20$ \\
5 & Concrete & $0.15-0.30$ \\
\hline
\end{tabular}

Source. Young, 2008.

buildings in Ghana and recommends some remedial measures with Kumasi and Ejisu as case study.

\section{Literature Review}

The literature review focused on the causes, effects, and remedial measures for controlling and treating rising damp.

\subsection{Causes of Rising Damp}

2.1.1. Salt Attack. Rising damp is caused by capillary suction of water through fine voids that occur in all masonry materials. Capillaries draw water from the soils beneath a building against the force of gravity leading to damp zones at the base of walls [11, 12]. In most cases, dampness contains some amount of salt. It must be noted that the main source of moisture rise is the availability of water in the soil, which in its natural form contains various types of soluble salts $[13,14]$. The slow process of absorption of water into block wall with subsequent evaporation leads to gradual deposit of salts in masonry walls. The masonry wall acts as a filter system for impure water as the various soluble salts are drawn into the wall and are left behind [15].

2.1.2. Porosity of Building Materials. The amount of water a material absorbs depend on the volume of the interconnected pore space. Rising damp occurs in materials with high rate of porosity such as sandcrete block and concrete [16]. Materials with a lot of very small pores are generally less durable than materials with fewer but larger pores. All masonry materials, whether stone, brick, mortar, earth, or concrete block, are porous to some degree. Porosity is a rough guide to durability $[17,18]$. Table 1 shows the degree of porosity of some building materials.

2.1.3. Workmanship. The durability of a building is greatly dependent on the quality of workmanship, specifications, and the design details. Lack of understanding of design details, specification, and poor workmanship on the part of artisans has contributed to many modern buildings with maintenance problems [19]. The quality of construction methods and the attention to details are of great importance. When artisans fail to comply with standards and specifications in design, the result leads to rising damp [20]. The building industry in Ghana is however dominated by artisans who have little knowledge in construction technology [21, 22]. Inadequate knowledge on the part of artisans makes it very difficult for them to understand and implement basic principles

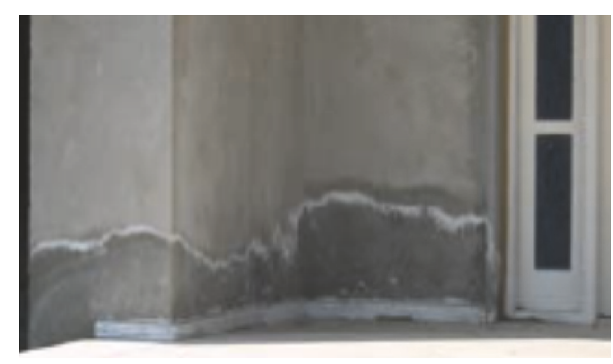

FIgURE 1: Tidal mark on wall in Kumasi.

of construction practices and has created lots of problems in many residential buildings. Artisans have assumed the role of building professionals. A craftsman understands the technology of his craft and can provide leadership to do quality work. This emphasizes the need for training of artisans across the country in modern trends in building construction [23].

2.2. The Effects of Rising Damp. The World Health Organization publications on "Damp and Mould" (WHO, 2009) indicated that, in Europe, between 10 and 50\% of the indoor environment, where people live, work, and play, are damp as a result of humid conditions [9]. Humid walls create coldness, which require more heating energy leading to increase in energy bills. This buttresses the need to consider thermal conductivity materials of various types in relation to dampness. The rate of evaporation on the external wall is related to the nature of wall surfaces, climate, orientation, and location [24]. As moisture evaporates from both sides of the wall, more water is drawn from the ground and a continuous upward flow of water occurs. The upward movement of water causes stains on internal walls, crumbling of plastered surface, paint peel off, and leaving a musty smell. On the external walls, signs of rising damp can usually be seen at the base of the masonry walls, where crumbling plaster and peeling paint are evidence. Severely affected masonry exhibits extensive decay, and powdery salt residue can clearly be seen at the base of the wall resulting into efflorescence, tide mark, mould, and fungi [25]. Dampness in walls of buildings lead to physical, biological, or chemical deterioration of building materials. The presents of damp also affect the quality of air in relation to human health and comfort. According to the WHO (2009), some occupants of damp rooms are at risk of experiencing health problems such as respiratory infections, allergic rhinitis, and asthma [10]. Damp also affect the structural integrity of timber products, walls, and thermal insulation in buildings [26]. Figures 1 and 2 show tidal mark and growth of mould and fungi effects, respectively.

\section{Methods of the Study}

Descriptive and quantitative research approach were adopted for the study. The main source of data collection was obtained from peer-reviewed journals articles and text books. The study also conducted case study at some building construction sites in Kumasi and Ejisu. The study used purposive 
TABLE 2: The sample size for the survey.

\begin{tabular}{lccc}
\hline Professionals & Questionnaire distributed & Responsive questionnaire returned (\%) & Percentage \\
\hline Civil engineers & 30 & 28 & 93 \\
Architects & 30 & 24 & 80 \\
Quantity surveyors & 30 & 26 & 87 \\
\hline Total & 90 & 78 & \\
\hline
\end{tabular}

TABLE 3: Year of experience of professionals.

\begin{tabular}{lcc}
\hline Number of years with rising damp & Frequency & Percent $(\%)$ \\
\hline $1-5$ years & 24 & 30 \\
$6-10$ years & 34 & 44 \\
$11-15$ years & 10 & 13 \\
$16-20$ years & 10 & 13 \\
\hline Total & 78 & 100 \\
\hline
\end{tabular}

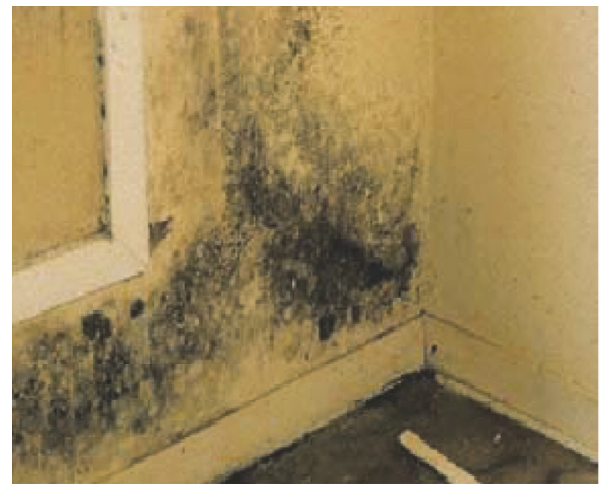

FIGURE 2: Moulds on walls in Ejisu.

snowball sampling techniques in selecting professionals for the study [27]. Structured questionnaires were administered to obtain information from the selected building professionals who have worked on rising damp. The questionnaires covered the demography of the respondent, causes, effects, and remedies of controlling rising damp. Both open and close ended questions were used in obtaining views of the respondents. Questionnaires were administered to quantity surveyors, civil engineers, and architects who were practicing in the Kumasi and Ejisu assemblies.

3.1. Analysis of Data. The data collected were analyzed using Statistical Package for Social Statistics version 20. Relative Importance Index (RII) was used to determine the relative significance of one factor compared to other variables in the same category $[28,29]$. The RII was calculated using the formula,

$$
\text { Relative Importance Index (RII) }=\frac{\sum W}{A N},
$$

where $W$ is the weights given to each variable by the respondents, ranging from 1 to $5, A$ is the highest weight (i.e., 5 in the study), and $N$ is the total number of samples.
Ninety (90) questionnaires were designed and administered to selected built environment professionals within Kumasi and Ejisu. Seventy-eight (78) responsive questionnaires were retrieved as indicated in Table 2.

\section{Results and Discussions}

4.1. Responses from Professionals. The working experience of respondents and their knowledge in rising damp were discussed. Table 3 indicated that almost $70 \%$ of the respondents were involved in the treatment of rising damp over 5 years.

4.1.1. The Causes of Rising Damp. The study revealed that all the sampled professionals considered the failure to use dampproof membrane as the main cause of rising damp with a total weight of 163 and a Relative Important Index (RII) of 0.836 . Failure to use damp-proof course was ranked second in Kumasi and Ejisu with a total weight of 160 and a RII of 0.821 . Groundwater with a total weight of 155 and porosity of masonry and absence of concrete floor bed at substructure which has a total weight of 152 were ranked 3rd and 4th, respectively, as causes of rising damp. Flooding and type of soil and sand were ranked 5th and 6th, respectively. The least ranked causes of rising damp were the weather and construction water with total weights of 104 and 94, respectively, as shown in Table 4.

4.1.2. Remedies for Controlling Rising Damp. The study identified different methods of controlling rising damp as indicated in Table 5. And the selected building professionals were asked to rank the most effective and efficient remedial measures for controlling and treating rising damp based on their professional experience. Undersetting and saw slotting with RII of 0.882 and 0.862 were ranked 1st and 2nd, respectively. Making good plumbing leakages and the use of approved waterproof chemical injection were ranked 3rd and 4th, respectively. Replastering crumbled masonry and repainting were the least at 13 th and 14 th, respectively.

4.2. Field Study. The study also contacted site inspections of some on going works and existing buildings where practices 
TABLE 4: Causes of rising damp in buildings.

\begin{tabular}{|c|c|c|c|c|}
\hline Number & Causes & Mean & RII & Rank \\
\hline 1 & Failure to use damp proof membrane & 4.19 & 0.84 & 1 \\
\hline 2 & Failure to use of damp proof course & 4.10 & 0.82 & 2 \\
\hline 3 & High water table & 3.97 & 0.80 & 3 \\
\hline 4 & No concrete floor bed at substructure & 3.90 & 0.78 & 4 \\
\hline 5 & Flooding & 3.49 & 0.70 & 5 \\
\hline 6 & Type of soil & 3.38 & 0.68 & 6 \\
\hline 7 & Plumbing leakage & 3.31 & 0.66 & 7 \\
\hline 8 & Type of cement & 3.18 & 0.64 & 8 \\
\hline 9 & Presents of chemicals & 3.10 & 0.62 & 9 \\
\hline 10 & Short roof overhang & 2.92 & 0.58 & 10 \\
\hline 11 & Run-off water & 2.85 & 0.57 & 11 \\
\hline 12 & Methods of construction & 3.27 & 0.55 & 12 \\
\hline
\end{tabular}

TABLE 5: Ranking of remedial measures for controlling and treating rising damp.

\begin{tabular}{|c|c|c|c|c|}
\hline No. & Remedial measures for controlling rising damp & Mean & RII & Rank \\
\hline 1 & Undersetting (insertion of damp proof course and membrane under masonry wall) & 4.41 & 0.88 & 1 \\
\hline 2 & Saw slotting (insertion of damp proof course and membrane under masonry wall) & 4.31 & 0.86 & 2 \\
\hline 3 & Making good plumbing leakages & 4.18 & 0.84 & 3 \\
\hline 4 & Using approved water proof chemical injection & 3.95 & 0.79 & 4 \\
\hline 5 & Application of addictive in mortar and concrete & 3.90 & 0.80 & 5 \\
\hline 6 & Provision of subsoil drainage system around the building (high water table zone) & 3.67 & 0.73 & 6 \\
\hline 7 & Application of water repellant coating (bituminous compound) & 3.54 & 0.71 & 7 \\
\hline 8 & Provision of aprons and drains & 3.51 & 0.70 & 8 \\
\hline 9 & Tyrolean finish to wall surfaces & 3.44 & 0.70 & 9 \\
\hline 10 & Terrazzo finish to wall surfaces & 3.38 & 0.68 & 10 \\
\hline 11 & Provision of long roof overhang & 3.36 & 0.67 & 11 \\
\hline 12 & Tiling the wall surfaces & 3.15 & 0.63 & 12 \\
\hline 13 & Replastering crumbled masonry & 2.97 & 0.60 & 13 \\
\hline 14 & Repainting & 2.56 & 0.5 & 14 \\
\hline
\end{tabular}

leading to the cause of rising damp were in operation. The following were some of the observations at various building construction sites in Kumasi and Ejisu in Ashanti Region of Ghana.

4.2.1. Failure to Use Damp-Proof Material. The straight method of building construction, where sandcrete block wall starts from foundation to superstructure lintel without floor bed concrete and damp-proof materials, was in practice. All the new building sites visited were identified with these poor construction practices. These practices promote speedy capillary action causing rising damp in most buildings. As shown in Figure 3, the arrow shows the boundary between the foundation and superstructure masonry block where there is no floor concrete bed and no damp-proof material. These practices were mostly found at private construction sites.

4.2.2. Cladding on Wall Surface. Buildings experiencing rising damp were cladded with the use of wall tiles, marble stones, and tyrolean finish as shown in Figure 4. The study revealed that these methods were ineffective due to the continual capillary action through the pores of the block wall from the foundation [30]. The finish losses bonding and rising damp reappeared above as shown in Figure 4.

4.2.3. Artisans' Lack of Appreciation of the Use of Damp-Proof Materials. The study observed that most of the artisans at the private building sites visited did not understand the concept and the application of damp-proof materials. It was revealed that the artisan handled the material (polythene) arbitrarily without due recognition, leading to holes, inadequate lapping, and discontinuation of the damp-proof material as shown in Figure 5 by the arrow. At some sites the material was wrongly placed. These acts by artisans make the provision of material ineffective.

4.2.4. Nontesting of Plumbing Service Pipe. Rising damp was identified in buildings particularly where service pipes had busted and leaked under paved compound and were not detected on time. These were prevalent in new completed buildings where testing of an entire plumbing installation was not done before ground paving, as shown in Figure 6. Lack of regular monitoring and maintenance of plumbing works was identified as one of the causes of rising damp in buildings. 


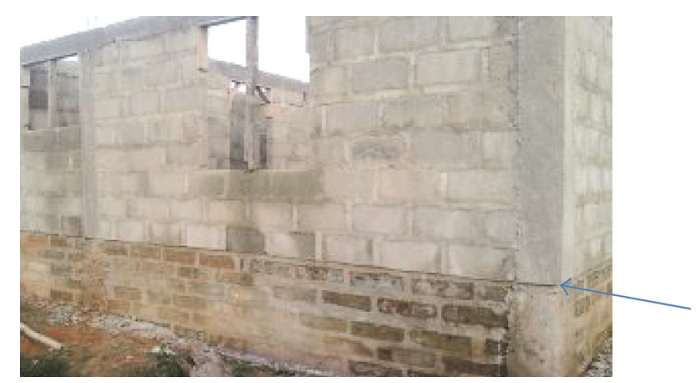

FIGURE 3: Building without floor concrete bed.

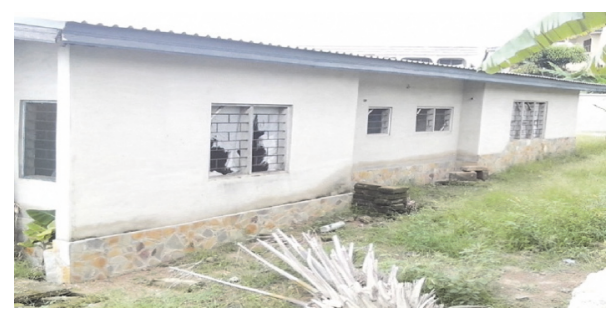

FIGURE 4: Rising damp above marble stone.

4.2.5. Application of Bitumen. The application of water-based bitumen compound to wall with rising damp crinkled and flaked off due to moist within wall as shown in Figure 7. The moist in wall caused loss of adhesion of the bitumen compound on the wall surface.

\section{Recommendations}

The selected building professionals for the study (civil engineers, architects, and quantity surveyors) recommended that, undersetting and saw slotting, are the main remedial measures for controlling and treating rising damp in buildings that have already affected with damp.

The study recommend that all plumbing fittings and fixtures should be tested to detect leakages, making them good before finish works commence. Also, the use of tyrolean, terrazzo, and tilling is not effective and efficient measures of remedying rising damp, undersetting and saw slotting are the most recommended methods. Proper placement of dampproof materials in all foundation works for new buildings construction should be strictly enforced by consultants irrespective of the type of soil or geographical location.

Consultants, and site supervisors should ensure that damp-proof materials are always part of their specifications and also indicate how it should be used. Artisans should be educated on the right application of damp-proof materials and their functions. Construction of block work from foundation to superstructure lintel, without ground floor bed concrete, should not be accepted by consultants.

The study recommends that $15 \%$ of fine aggregate should be replaced with fine granite (quarry dust); this will help reduce the drastic effect of chemical attach emanating from sulphate in the fine aggregate.

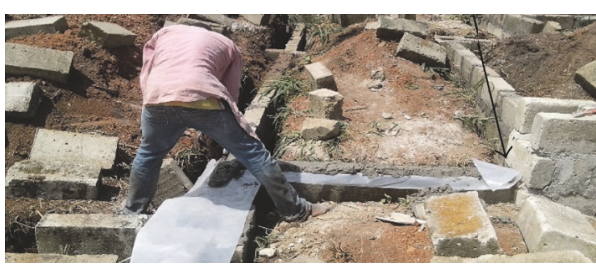

FIGURE 5: Placing of damp-proof material in foundation.

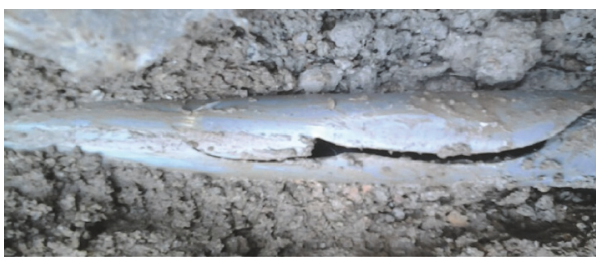

Figure 6: A burst PVC pipe beneath paved compound of a house.

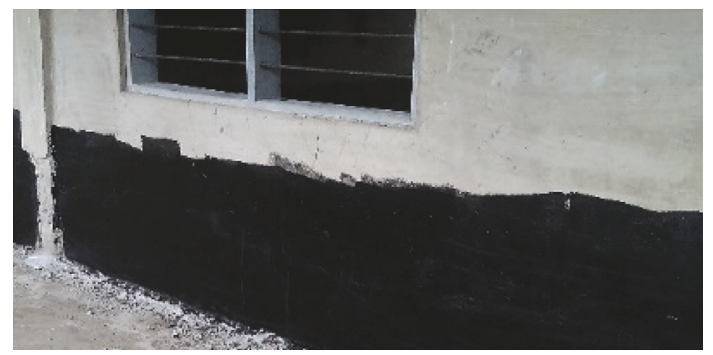

FIGURE 7: Bitumen applied before painting.

\section{Conclusions}

The study identified that failure of not using damp-proof materials, damp-proof coarse, high water table, and construction of block work from substructure through superstructure with no concrete floor bed at the substructure are some of the causes of rising damp in completed buildings.

The selected building professionals concluded undersetting, saw slotting, and making good plumbing leakages as some of the means of treating existing buildings affected with damp and that the use of tyrolean, terrazzo, and tiles should not be used to cover damp affected areas in buildings. The professionals also concluded that all new foundation should have rising damp preventive materials. One such common material is the use of common $600 \mathrm{~mm}$ micron polythene for preventing moisture rise in buildings. The study concludes that all parties in the building industry (consultants and contractors) should ensure that works are done according to standards and specification with efficient supervision.

\section{Conflicts of Interest}

The authors declare that there are no conflicts of interest regarding the publication of this paper. 


\section{Acknowledgments}

The authors would like to show their utmost gratitude to Miss Olivia Abanyo and Miss Anna Frema Bonsu for their secretarial support.

\section{References}

[1] British Research Establishment (BRE), Good Repair Guide 6, Treating Rising Damp in Houses, BRE Press, 1997.

[2] T. Hutton, Rising Damp" article reproduced from The Building Conservation Directory 1998 and revised February 2012.

[3] F. Moreno, S. A. G. Vilela, Â. S. G. Antunes, and C. A. S. Alves, "Capillary-rising salt pollution and granitic stone erosive decay in the parish church of Torre de Moncorvo (NE Portugal)implications for conservation strategy," Journal of Cultural Heritage, vol. 7, no. 1, pp. 56-66, 2006.

[4] Z. Zhang, "A Review of Rising Damp in Masonry Buildings," in Advanced Polymer and Composites (APC) Research Group, Department of Mechanical and Design Engineering, 2010.

[5] D. Young, Salt Attack and Rising Damp A Guide to Salt Damp in Historic and Older Buildings. A Technical Guide for Heritage Council of NSW · Heritage Victoria · South Australian Department for Environment and Heritage - Adelaide City Council. 2008.

[6] G. Ahmad and A. H. F. Raman, "Treatment of salt attack and rising damp in heritage buildings in Penang," Malaysia. Journal of Construction in Developing Countries, vol. 15, no. 1, pp. 93-113, 2010.

[7] J. Hetreed, Damp House: A Guide to the Causes and Treatment of Dampness, 2008.

[8] A. E. Charola, "Salts in the deterioration of porous materials: an overview," Journal of the American Institute for Conservation, vol. 39, no. 3, pp. 327-343, 2013.

[9] G. Sena-Kportufe, "The Devastating Effects of Rising Damp in the Construction Industry Lecturer," Industrial Engineering Letters, vol. 5, no. 10, 2015.

[10] WHO Regional Office for Europe.DAMP AND MOULD Health risks, prevention and remedial actions Information brochure, 2009.

[11] K. Agyekum, J. Ayarkwa, C. Kora nteng, and E. Adinyira, "Level of knowledge of building occupants on dampness in walls of residential buildings in Ghana," Modern Management Science \& Engineering, vol. 1, no. 2, 2013.

[12] K. Agyekum, J. Ayarkwa, and C. Koranteng, "Holistic diagnosis of rising damp and salt attack in two residential buildings in Kumasi, Ghana," Journal of Construction Engineering, vol. 2014, Article ID 398627, 13 pages, 2014.

[13] K. Agyekum, J. Ayarkwa, and C. Koranteng, "Perceptions of Building occupants on effectiveness of practiced damp remediation measures in Ghana," Journal of Environment and Earth Science, vol. 4, no. 1, 2014.

[14] R. Burkinshaw, "Rising damp: part 1. Case study examples and the Lambeth Pier Test: how to isolate ground-sourced rising damp by the "Burkinshaw Test Method," Journal of Building Survey, Appraisal \& Valuation, vol. 1, no. 1, pp. 1-15, 2011.

[15] K. Agyekum, J. Ayarkwa, C. Koranteng, and E. Adinyira, "Preliminary assessment of dampness in walls of residential buildings in four climatic zones in Ghana," Journal of Sustainable Development, vol. 6, no. 9, 2013.
[16] P. Lopez-Arce, E. Doehne, J. Greenshields, D. Benavente, and D. Young, "Treatment of rising damp and salt decay: the historic masonry buildings of Adelaide, South Australia," Materials and Structures, vol. 42, no. 6, pp. 827-848, 2009.

[17] S. Zsembery, Manual 2: The Properties of Clay Masonry Units, Clay Brick and Paver Institution, Baulkham Hills, Sydney, Australia, 2001.

[18] A. E. K. Hanan, A. E. Nouhy, and G. Abdel-Hameed, "Assessment of Porous concrete properties as a function of mix proportions," in World Applied Sciences Journal of Building Materials and Quality Control Institute, Housing and Building National Research Center, Giza, Egypt, 2013.

[19] B. Kuriakose, “Thinking Basics," IA \& B at IIT, Chennai, India, 2008.

[20] J. A. Al-Khatam, Buildings Maintenance Cost. Master of Engineering Report [Master, thesis], King Fahd University of Petroleum \& Minerals, Dhahran, Saudi Arabia, 2003.

[21] C. Koranteng and G. E. Abaitey, "Simulation based analysis on the effects of orientation on energy performance of residential buildings in Ghana," J Sci Technol, vol. 29, pp. 86-101, 2009.

[22] G. Ozay and N. Ozay, "The Most Common Defects on Housing Surfaces in Northern Cyprus," in World Congress on Housing Transforming Housing Environments through Design, Department of Civil Engineering Eastern Mediterranean University, Magusa,Turkey, 2005.

[23] H. de Clercq, "The effect of other salts on the crystallization damage to stone caused by sodium sulphate," in Proceedings of the Salt Weathering on Buildings and Stone Sculptures, pp. 22-24, Copenhagen, Denmark, October 2008.

[24] Nawkaw Corporation. Efflorescence Solutions for Masonry and Concrete. A Nawkaw White Paper. Nsw Heritage Office, (2004). Rising Damp. The Maintenance Series. Heritage Council of NSW Technical Advisory Group, Australia.2010.

[25] E. Rirsch and Z. Zhang, "Rising damp in masonry walls and the importance of mortar properties," Construction and Building Materials, vol. 24, no. 10, pp. 1815-1820, 2010.

[26] P. Trotman, C. Sanders, and H. Harrison, "Understanding Dampness: Effects, Causes, Diagnosis and Remedies," in Diagnosis and Remedies, vol. 466 of $\mathrm{Br}$ Series, BRE Bookshop, Garston, Watford, 2010.

[27] M. Saunders, P. Lewis, and A. Thornhill, Research Methods for Business Students, Pearson Education, Harlow, UK, 5th edition, 2009.

[28] C. Tengan, L. F. Anzagira, E. Kissi, S. Balaara, and C. A. Anzagira, "Factors affecting quality performance of construction firms in Ghana," Evidence from Small-Scale Contractors. Civil and Environmental Research, vol. 6, no. 5, pp. 2225-0514, 2014.

[29] A. B. Agyakwa-Baah and F. D. K. Fugar, "Factors Causing Delay in Building Construction Projects," in Proceedings of the 1st International Postgraduate Research Conference on the Built Environment, Kumasi, Ghana, 2010.

[30] L. Pel, H. Huinink, and K. Kopinga, "Salt transport and crystallization in porous building materials," Magnetic Resonance Imaging, vol. 21, no. 3-4, pp. 317-320, 2003. 


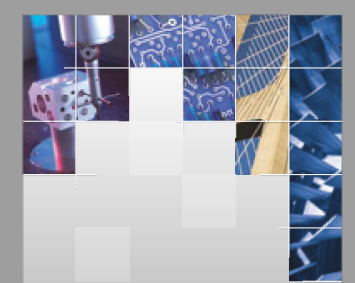

\section{Enfincering}
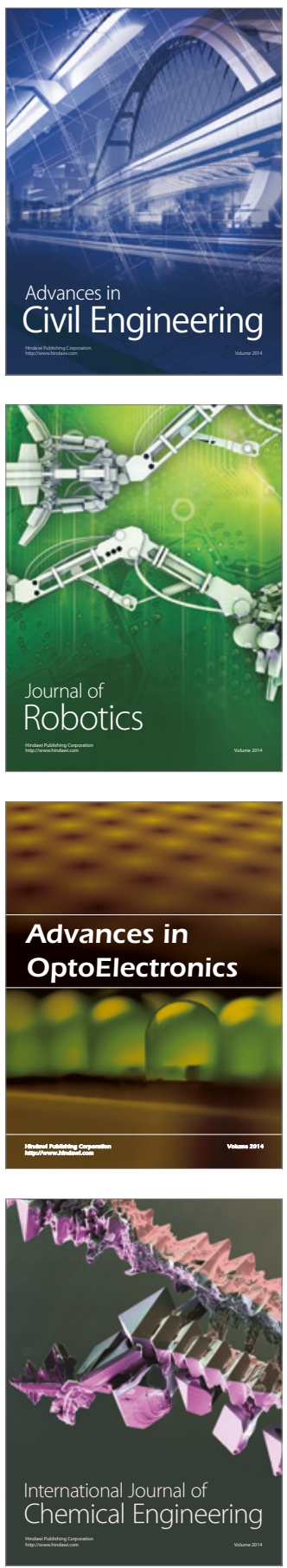

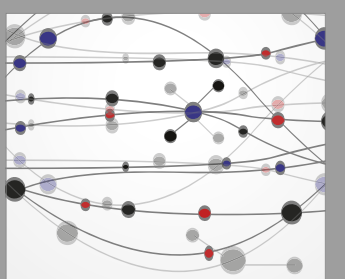

The Scientific World Journal

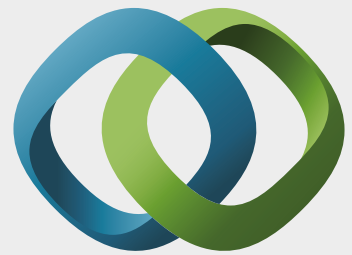

\section{Hindawi}

Submit your manuscripts at

https://www.hindawi.com
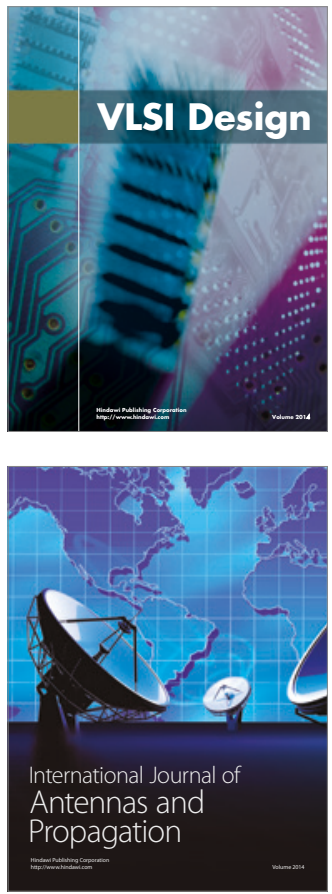

\section{Rotating}

Machinery
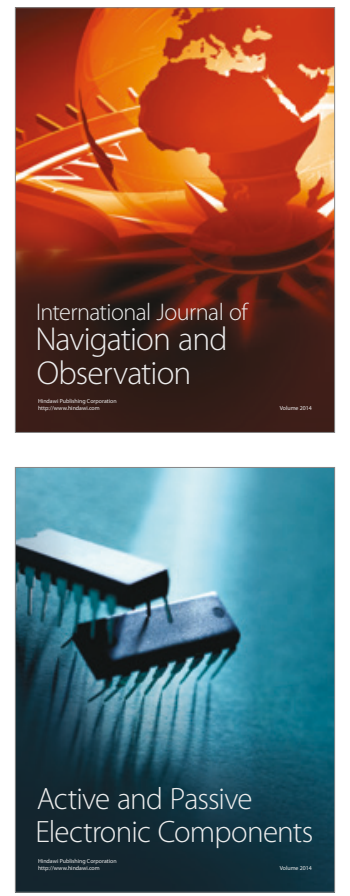
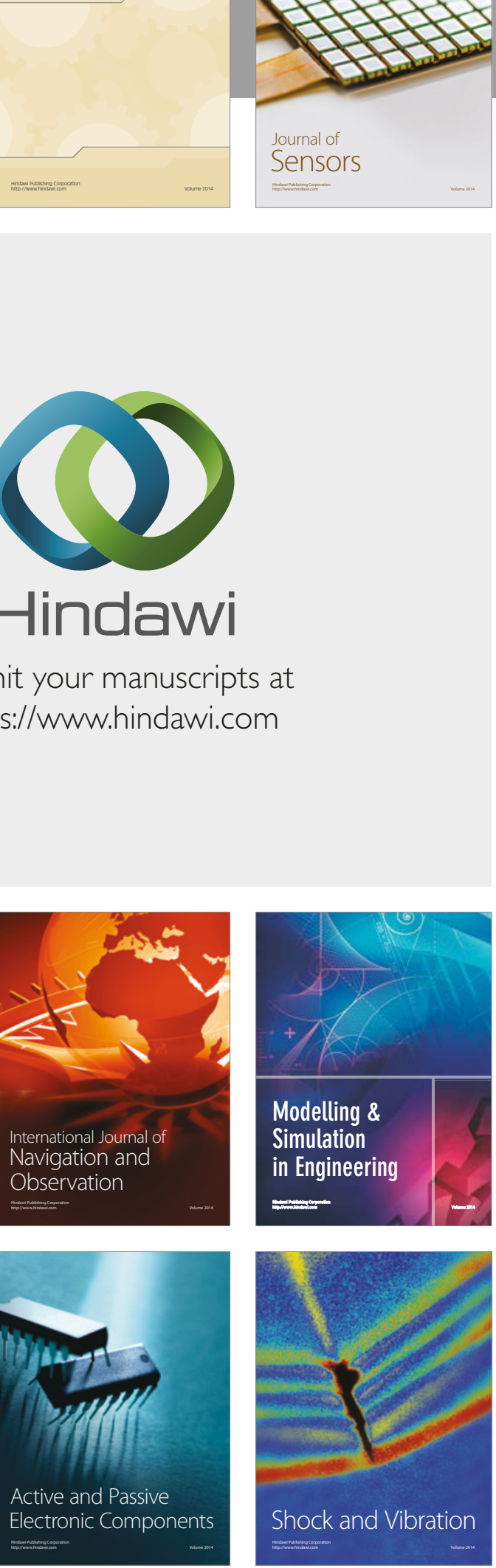
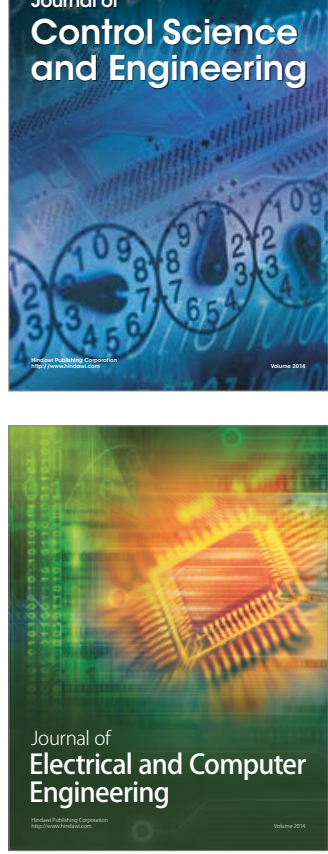

Distributed

Journal of

Control Science

and Engineering
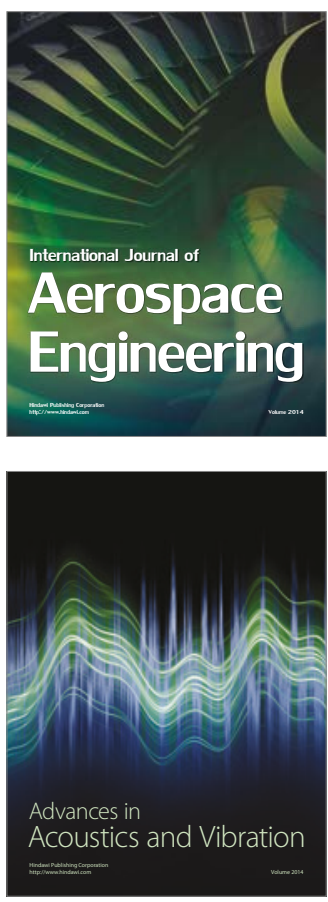

Sensor Networks 